\title{
Exploring the Causal Factors and the Effects of Sexual Harassment on Female Students at the Universities in Africa. An Overview
}

\author{
J.G. Kheswa \\ Department of Psychology, University of Fort Hare, Private Bag X1314, Alice, 5700, South Africa. \\ Email: jkheswa@ufh.ac.za
}

Doi:10.5901/mjss.2014.v5n20p2847

\begin{abstract}
The reinforcement of male dominance and heterosexuality are often the cause of sexual harassment of female students at the institutions of higher learning across Africa. Drawing from socio-cultural and social exchange theories, female students find themselves in awkward positions to resist condom - use because economically they are dependent on their male partners. This research paper sought to explore the manner in which quid pro quo plays a role in effecting sexual advances between lecturers and female students. Having employed various peer-reviewed articles, books, dissertations and internet journals on sexual harassment as a methodology, the other aim of this paper was to highlight the detrimental effects of sexual harassment on the educational and psychological aspects of females attending tertiary institutions. The findings revealed that victims of sexual harassment including lesbians, suffer from PTSD, neuroticism and most likely to contract sexually transmitted infections. Given the findings of the study, the recommendations are that: unconditional support from the police and those in Health Care Centres be provided; lesbians be respected as well especially in countries such as South Africa where the Section 29 of the Constitution, Bill of Rights, protects the rights of every person regardless of gender and sexual orientation.
\end{abstract}

Keywords: Female students, quid pro quo, harassment, discrimination, abuse.

\section{Introduction}

There have been studies and reports on gender violence in the form of sexual harassment in higher education for the past three decades (Morley, 2012) and this affects female students' psychological well-being tremendously, owing to their socio-economic status and how they are perceived from political and socio-cultural perspectives. The term " sexual harassment" was coined in the 1960s by feminists after they contended that the legal system, being male- dominated in many organisations, lack understanding of how women feel after they have been sexually harassed ( Oswalt \& Wyatt, 2007). According to Willness (2007), sexual harassment is a form of gender discrimination that involves unwelcomed sexual advances, requests for sexual favours and non-verbal or physical conduct of a sexual nature. It can be further explained as educational discrimination consisting of unwelcomed verbal or physical conduct directed at a student because of her sex. It can be concluded that anyone who deliberately or repeatedly makes unwelcomed verbal comments, gestures or physical contact of a sexual nature is engaging in a sexual harassment.

This article seeks to contribute to the analysis of sexual harassment by specifically addressing the causal factors, effects and strategies that could be employed to combat sexual harassment or gender-based violence in the institution of higher learning. This paper will progress in three ways as indicated in the above sentence. The recent research studies conducted from around the world will be integrated as well as various theories which underpin the subject. But first, the concept sexual harassment will be explained.

\section{Sexual Harassment}

According to Pierce (2003), sexual harassment may include some request for sexual favours either directly or by implication: sometimes ordered in exchange for rewards such as academic success or promotion. In this context, the female student may be deliberately touched, kissed or fondled and brushed against her will by male students or lecturers. Very often, sexually oriented or obscene comments, for example comments about a person's physical appearance or sexuality may be directed at her coupled with being questioning persistently about her private life. Furthermore, uninvited visits, displays of erotic materials such as posters, photographs and pornography and threats of physical assault via cell phones, they all amount to sexual harassment. According to Dastile (2004), the University of Venda in South Africa had 
several incidents of sexual harassment from the year 2000 to 2004 from different female students in different departments. A female student enrolled in Bachelor of Arts, a non-resident and a class representative, was sexually harassed by the lecturer when she went to call the lecturer for a lecture. The lecturer touched the student, hugged and kissed her in his office and this happened more than once. The student felt uncomfortable and irritated. This brought back past memories of earlier rape to the victim by her cousin.

\subsection{Quid pro quo}

According to Bauemeister (2001), the first form of sexual harassment is quid pro quo harassment. A quid pro quo harassment usually takes place when a female student is coerced into having sex with her lecturer(s) under the threat of failing a course. Willness (2007) assert that quid pro quo harassment is equally unlawful whether the student resists and suffers the threatened harm or remains submissive to avoid victimization. In Ghana, some male students expressed dissatisfaction when asked if there are sexual exchanges prevailing at Public University. Nineteen male students who were interviewed articulated that women's academic successes were attributable to quid- pro quo, and passed by fraudulent means (Morley, 2011). A male student was quoted as follows:

"Sometimes you will see a woman or lady in a class or maybe in a group discussion once ... you wonder how she got an admission? But when the paper comes she performs better than you..... sometimes women have been favoured"

\subsection{Gender -based discrimination}

Sexual harassment is a form of gender based discrimination and affects a greater proportion of female students. Genderbased discrimination rather reflects intrusive, unwanted and coercive sexual attention from which there is frequently no viable escape. Sexual coercive men tend to view gender interactions as based on rules and scripts that are somewhat exploitative and sometimes ignored. In this regard, males may use force or aggression to obtain sex, thus rape (lliyasu, Abubakar, Aliyu, Galadanci, \& Salihu; Kheswa, Dayi \& Gqumani, 2014). Sexual coercion is sexual activity or other sexlinked behaviour by threat of punishment and examples include negative performance evaluation, withholding of examination results or threats of failing a student. Sexual assault can be uninvited touching, kissing or rape. This also includes date raping, Finn (2004). Bauemeister (2001) added that it has been proven that in most cases/accounts, women are sexually coerced in their intimate relationships.

\subsection{Hostile- environment}

According to Bauemeister (2001), hostile environment harassment is the second form of sexual harassment in which female students are subjected to repeated offensive and denigrating sexual comments and behaviour. Willness (2007), adds that this sexual harassing conduct (which can include unwelcomed sexual advances, requests for sexual favours and other verbal, nonverbal, or physical conduct of sexual nature) by lecturer, another student, or a third party that is sufficiently severe, persistent, or pervasive to limit a student's ability to participate in or benefit from an education program or activity, or to create a hostile or abusive educational environment, causes a lot of problems for the female students.

\subsection{Moral deficit}

According to Imonikhe, Idogho and Aluede (2011), there are female students who can push themselves to sexual harassment by seducing male tutors or lecturers to assist them to write their examination or be awarded unwarranted grades in the examination. Through seductive behaviour, female students may insist requests for dinner, drinks or dates, persistent excuses when they have missed deadlines for submission of assignments, phone calls and other invitations (Finn, 2004). One way of doing this could be their dress-code when attending lectures or lecturers' offices. In a study conducted in Nigeria, Imonikhe and colleagues (2011) found that lecturers cited that as a result of revealing attire worn by female students, they hardly concentrate, hence they make sexual advances. The solicitation of sexual activities or other sex-linked behaviour, promises of rewards and the proposition either explicit or subtle is called sexual bribery (Finn, 2004). 


\subsection{Intergenerational relationships and socio-economic status}

Studies have found a positive relationship between increased age of male partners who are economically stable and increased risk for HIV transmission, denied pregnancy and abortion (Luke, Goldberg, Mberu \& Zulu, 2011; Takatshana, 2013). Female students who date older men or "sugar daddies" stay in those relationships because they are characterized by money to pay for their fees and alleviate poverty and contribute to their social status among peers (Gordon \& Colllins, 2013). For fear of losing money for jewellery, make-up, clothes, they tend to settle in abusive relationships irrespective that their sexual partners abdicate condom-use (Luke \& Kurtz, 2002). In Zimbabwe, Shumba and Matima (2002) found that female students' poverty provides ideal pre-conditions for sexual bartering.

\section{Theoretical Framework}

The causes of sexual harassment are supported by various theories. Theory of motivation by Abraham Maslow postulates that before an individual attains growth needs (e.g self-actualization), the deficiency needs must firstly be met (e.g physiological, safety and security needs) (Nicholas, 2008; Swartz, de la Rey, Duncan, Townsend \& O'Neill, 2011). However, if the female students' financial background is below poverty-line, chances of engaging in transactional sex are high (Luke, Goldberg, Mberu \& Zulu, 2011). This group of students may find themselves in compromising situation of abandoning condom use because their economic survival depends on sexual barter, thus social -exchange theory. As for the lesbians (women whose sexual orientation centres around erotic, emotional and social connectedness to people of the same gender) it is socio-cultural theory that contributes to their sexual harassment because of stereotypic dimensions and gender constructs that women cannot be sexually attracted to other women (Swarr \& Nagar, 2004). Following Douglas and Wildavsky's (1983) argument of cultural risk theory (group and grid), uncivilised men expect women to be submissive and act according to evolution, whereby they are expected to be pregnant and not being intimately involved with other women. To behave in contrast to heterogeneity, lesbians suffer a variety of abuse.

\section{The Effects of Sexual Harassment}

According to Silva and Hill (2005), the effects of sexual harassment in the cases above ranged from stress related symptoms such as loss of memory to self blame, lack of trust and concentration in class. Changes in the lifestyles of the victims include non-attendance of classes as well as cancellation of courses. The types of sexual harassment and the forms as well are extremely widespread at universities and everywhere in the community. According to Campbell, Cabral and Dworkin (2009), sexual harassment can be devastating and most sexual harassments have nothing to do with flirtation or sincere sexual or social interest. Rather it is offensive, often frightening and insulting to women. Women are often forced to leave universities to avoid sexual harassment and some individuals might experience serious psychological, social, educational and emotional -related problems. Sexual harassment does not happen because women dress provocatively or initiate sexual activity in the hope of getting promoted or advancing their careers. Victims of sexual harassment vary in physical appearance, type of dress and behaviour. The only thing they have in common is that over $99 \%$ of them are females. To support this notion, a study was conducted by the Connecticut Department of Education with 308 female students, 235 male students and 4 participants who did not state their gender. It was evident that $92 \%$ of the female students were harassed since they started school, Stein (2000).

According to Quaicoe-Duco (2010), female students who are sexually harassed by their male classmates, do not finish their work because they will be pestering around. Sexual harassment makes universities a dangerous place to be for female students. Even though South African female students have better access to universities than many of their counterparts in other sub-Saharan African states, they are confronted with levels of sexual harassment in universities that impede their access to education on equal terms with male students.

\subsection{Educational effects}

According to Quaicoe-Duco (2010), sexual harassment has a destabilising effect on the education of female students. The academic performance of the female students suffers. The female students find it very hard to concentrate on their work. Some even lose interest in studying and transfer to new universities or simply leave school as a result of hopelessness and pregnancy if they had unsafe sex with their perpetrators. Cementing these experiences is Astin's theory of student involvement, which states that sexually harassed students may display avoidance behaviour which includes the environment that promotes such behaviour (Okeke, 2011). In this way, academic growth may be impeded 
and contribute to low self-esteem and low self-efficacy (Schwartz, 2000). Silva and Hill (2005) explained that social workers and therapists working with sexually harassed female students report that, some students encounter problems in their courses hence they are not able to finish their degree.

\subsection{Psychological effects.}

According to Campbell et al., (2009) cognitively, victims tend to form negative stereotypes in their minds about males and begin to ruminate and constantly check to see if there is anything that caused the male students or lecturers to sexually harass them and end up developing dissociative identity disorder (Comer, 2013). Individuals with dissociative identity disorder are preoccupied with constant checking of one's self in the mirror to an extent that their day to day functioning becomes grossly affected and experience aloofness and neuroticism because they are demotivated (Nolen-Hoeksema, 2008). This de-motivation can cause withdrawal and gradually develops into depression.

Various scholars postulate that sexual harassment can be very traumatic to the individual, female students can develop a phobia for men and may experience an intense anxiety, mood swings, become melancholic in the presence of men and prefer to stay inside the house (Bennett, Gouws, Kritzinger, Hames \& Tidimane, 2007; Comer, 2013; Ryckman, 2008; Nolen-Hoeksema, 2008). Silva and Hill (2005) elucidate that sexual assault is one of sexual harassment that causes victims to suffer severe or chronic effects, the same psychological effects such as rape. Victims become targets of retaliation, backlash or victim blaming after the incident of sexual assault. Indeed the treatment of the female victims during investigation can be ruthless and it can add further damage to the victim's psyche life.

\subsection{Social effects}

Quist-Arcton (2003) asserts that there is a list of environmental changes that might occur to sexually harassed victims. Should the people know about the harassment, the victim might wonder who knows and what they are thinking about the case. Also, the victim might overhear conversations from other students around her about her case and she might become the subject of gossip and derogatory information and speculations. As a result the judgements by all who know the victim, either negative or positive can create a huge burden to carry through the university environment (George, 2001). Franklin (2006), states that the victim can become publicly sexualised a walking icon of misplaced amorous attention. From this, Macneela and Bredin (2010) hypothesize that there could be immersion in alcohol consumption as a form of escapism which could aggravate their academic performance.

At the University of the Western Cape, South Africa, lesbian students who shared their ordeal of being involved with other women cited fears of disclosing their sexuality beyond the counselling room or with sympathetic lecturers or residence wardens for fear of hate-crime (Bennett et al., 2007). Hate crime and homophobia in the lives of black lesbians in South Africa seems to escalate as many brutal attacks have been left unreported due to stigma and discrimination at the police-stations.

\subsection{Emotional effects}

Due to the psychological, social and educational effects, the female victims may develop emotional problems as well). Female victims of sexual harassment become vulnerable and tend to experience an intense anger towards their perpetrators or all males around them (Ryckman, 2008). Feelings of anger are all typical of acute phase of the posttraumatic stress disorder. Anger is usually a central feature of a survivor's response to trauma. This anger could provide victims with an increased energy to persist when dealing with the fact that they had been subjected to sexual harassment even they have no strength to carry on (Schultz \& Schultz, 2013). According to Balick (2004), $68 \%$ of the female students who had been sexually harassed felt very upset about the sexual harassment they experienced, $55 \%$ felt embarrassed and $32 \%$ felt afraid and scared. To cope with stress, female students may be extroverts and promote risky sexual behaviour to enhance positive moods (Wiebe, Drew \& Croom, 2010) while in the process apply defence-mechanism such as denial (Comer 2013; Nolen- Hoeksema, 2008)

Dastile (2004), also comments on the lack of trust in the university in general which develops as a result of harassment. In most cases the victim and the perpetrator are usually acquainted with each other which can lead to lack of trust because the victim could have been dependent on the perpetrator. Victims might have seen the perpetrator as a role model. There is distrust to those who sincerely want to help them and hatred for the male perpetrators because of betrayal or violated trust.

The victims avoid certain places that might remind them of the incidence. A particular place or event may suddenly 
re-create aspects of harassment thus resulting in emotional reactions. Emotional responses following incidences of sexual harassment could also depend on the victim's history of sexual abuse. Sexual harassment could revive wounds from the victim's past such as prior incidents of rape or incest. In countries such as Ghana, Awusabo- Asare (1993), found that HIV will spread as female students are in concurrent sexual relationships with men who are traditionally granted sexual freedom.

\subsection{Sexually transmitted infections, physical injuries and unprepared motherhood}

Holborn and Eddy (2011) in a survey conducted in Gauteng Province, South Africa among young men, 31\% reported that their attitudes towards sexually harassing females was fuelled by how women dressed and they presumed that it was acceptable to rape women if they dressing revealing clothes. Forced sex being violent and leaving females vulnerable, Wingood and DiClemente (2013) found that it increases the risk of transmitting HIV. In forced vaginal penetration, abrasions and cuts commonly occur, thus facilitating the entry of the virus through the vaginal mucosa. Common physical injuries which occur during rape tend to include genital irritation, vaginal bleeding or infection, decreased sexual desire, pain during intercourse, chronic pelvic pain and urinary tract infections (Cohen \& Roth 2009).

\section{Way-Forward}

South Africa being the first African country and the fifth internationally to legalize same-sex marriages (Government Gazette, 2006), why should lesbians be ostracized and called izitabane a derogatory name for something filthy as if having homosexual tendencies is pathological? To date, homosexuality was removed from the Diagnostic Statistical Manual IV-TR in 1973 by American Psychological Association because extensive research indicates that one's sexual orientation is not a barometer to be used to classify intelligence as most lesbians whose support structures are financially and emotionally sound, succeed fairly well academically in the same way as heterosexual women rather than being reported as experiencing depressive symptoms and maladaptive behaviour (Lev, 2006). Health -Centres and Police Stations should be friendly in providing unconditional support when females have been harassed rather than to traumatize the victims by asking them whether they reached orgasms in cases of rape. In other words, a warm and caring environment within the campus such as Student Counselling Unit must have social workers, psychologists and peercounsellors who will provide psychotherapy in a confidential manner. Finally, the sexual harassment policies must be implemented and perpetrators be suspended or dismissed.

\section{References}

Awusabo-Asare, K., \& Anarfi, J. (1993). Experimental research on sexual networking in some selected areas of Ghana. Health Transition Review. Supplement, 3, 29-43.

Balick, D. (2004). How to stop sexual harassment in schools. American Association of University Women. ST N.W. Washington DC. USA.

Bauemeister, R. F. (2001). Social Psychology and Human Sexuality. Sheridan Books, Ann Arbor: Philadelphia.

Bennett, J., Gouws, A., Kritzinger, A., Hames, M., \& Tidimane, C. (2007). Hate crimes and homophobia in the lives of black lesbian South African. Routledge: London.

Camarasa, M. \& Heim, D. (2007). Gender Violence Effects Indicators. University of Oulu. Beijing: China

Campbell,R., Cabral, G. \& Dworkin, E. (2009). Trauma, Violence and Abuse. Vol 10(3), 225-243.

Cohen, L. J., \& Roth, S. (2009). The psychological aftermath of rape: Long-term effects and individual differences in recovery. Journal of Social and Clinical Psychology, 5(4), 525-534.

Comer, R. J. (2013). Abnormal Psychology. Library of congress: United States of America.

Dastile, N. P. (2004). Analysis and interpretation of data. M.Sc. dissertation: University of Pretoria. South Africa.

Douglas, M., \& Wildavsky, A. (1983). Risk and culture: An essay on the selection of technological and environmental dangers. Univ of California Press: Berkeley.

Finn, J. (2004). International violence. Journal of international violence, Vol 19(4): pp. 468-483.

Franklin, D. (2006). Conference, CE programs and training. National Psychology Association: USA

George, E. (2001). Sexual violence in schools. African policy electronic distribution: The African fund and American Committee in Africa: South Africa.

Gordon, S. F., \& Collins, A. (2013). " We face rape. We face all things": understandings of gender-based violence amongst female students at a South African university: original contributions. African Safety Promotion, 11(2), 93-106.

Gouws, A., \& Kritzinger, A. (2007). Dealing with sexual harassment at institutions of higher learning: Policy implementation at a South African university. South African Journal of Higher Education, 21(1), 68-84. 
Government Gazette. (2006). Civil Union Act. (Act 17 of 2006). Government Printers. Pretoria.

Iliyasu, Z., Abubakar, I. S., Aliyu, M. H., Galadanci, H. S., \& Salihu, H. M. (2011). Prevalence and correlates of gender-based violence among female university students in Northern Nigeria. African journal of reproductive health, 15(3), 123-133.

Imonikhe, J., Idogho, P., \& Aluede, O. (2011). A Survey of Teachers' and Students' Perception of Sexual Harassment in Tertiary Institutions of Edo State, Nigeria. African Research Review, 5(5), 412-423.

Kheswa, J.G., X. Dayi., \& Gqumani, P. (2014). African Adolescent Males and Rape in the Eastern Cape, South Africa: A Need for Sexuality Education. Mediterranean Journal of Social Sciences, Vol 5 (10), 541-550.

Lev, A. I. (2006). Disordering gender identity: Gender identity disorder in the DSM-IV-TR. Journal of Psychology \& Human Sexuality, 17(3-4), 35-69.

Luke N, Goldberg, R.E., Mberu, B.U., Zulu, E.M., (2011). Social Exchange and Sexual Behavior in Young Women's Premarital Relationships in Kenya. Journal of Marriage and Family, 73(5):1048-1064

Luke N., \& Kurz K. (2002). Cross-generational and transactional sexual relations in sub-Saharan Africa: prevalence of behaviour and implications for negotiating safer sexual practices. Washington DC, AIDS Mark, Population Services International and International Center for Research on Women.

MacNeela, P., \& Bredin, O. (2011). Keeping your balance freedom and regulation in female university students' drinking practices. Journal of health psychology, 16(2), 284-293.

Matlin, M. (2001). The psychology of women. (4th edition.). Thomson Wadsworth: USA

Morley, L. (2011). Sex, grades and power in higher education in Ghana and Tanzania. Cambridge Journal of Education, 41(1), $101-115$.

Morley, L. (2012). Sex, Grades and Southern Theory: the Impact of Feminist Research on Higher Education Globally. GEXcel Work in Progress Report Volume $X, 11,31$.

Nicholas, L. (2008). Introduction to Psychology. Cape Town: UCT Press

Nolen- Hoeksema, S. (2008). Abnormal Psychology. Media \& Research Update. (4th ed.). McGram- Hill Higher Education: Boston.

Okeke, C. M. A. (2011). Impact of Sexual Harassment on Women Undergraduates' Educational Experience in Anambra State of Nigeria. (Doctoral thesis). Seton Hall University: Nigeria.

Oswalt, S. B., \& Wyatt, T. J. (2011). Sexual orientation and differences in mental health,stress, and academic performance in a national sample of US college students. Journal of homosexuality, 58(9), 1255-1280.

Pierce, K. J. (2003). LABOR AND EMPLOYMENT REVIEW: Title VII and Same-Sex Sexual Harassment After Oncale-Uncertainty Lingers. COLORADO LAWYER, 32(6), 87-92.

Quaicoe-Duco, R. (2010). Sexual harassment in tertiary institutions- A- myth-reality. Pop culture projects. Uganda

Quist-Arcton, O. (2003). Fighting prejudice and sexual harassment of girls in schools. Global Policy Forum.

Ryckman, R.M. (2008). Theories of Personality. (9th ed.). Thomson Wadsworth: Belmont

Schultz, D.P., \& Schultz, S.E. (2013). Theories of Personality. (10 ed.). Wadsworth Cengage Learning: Australia

Schwartz, W. (2000). Preventing student sexual harassment. Eric cleaning house on urban education. Eric Digest no.16: New York

Shumba, A., \& Mantini, A. (2002). Sexual harassment of college students by lecturers in Zimbabwe. Sex Education, 2 (1): 45-59

Silva, E. \& Hill, C. (2005). Drawing the line: Sexual harassment on campus.American Association of University women foundation, USA.

Stein, N. (2000). Sexual harassment in schools. Facing sexual harassment in K-12 New York: Teacher's College Press. Columbia University

Swarr, A., \& Nagar, R. (2004). 'Discriminating Assumptions: Interrogating "Lesbians ". Struggles for Identity and Survival in India and South Africa'. Signs, 29 (2), 491-517.

Swartz, L., de la Rey, C., Duncan, N., Townsend, L., \& O' Neill, V. (2011). Psychology: an introduction. (3rd ed.). Oxford University Press: Cape Town.

Takatshana, S. (2013). The impact of alcohol on the sexual behavior of adolescent males in Nkonkobe Municipality. (M.Soc.Sc dissertation). University of Fort Hare: Alice

Wiebe, D. J., Drew, L. M., \& Croom, A. (2010). Personality, health and illness. Psychology, Wiley \& Sons, New York, 294-302.

Wilken, E.C., \& Badenhorst, J.W. (2003). A comparative analysis of sexual harassment policies at selected higher education institutions in South Africa. South African Journal of Higher Education, 17: 197-205.

Willness, R. (2007). A meta-analysis of Antecedents and consequences of workplace sexual harassment. Journal of personnel psychology,

Wingood, G. M., \& DiClemente, R. J. (2013). The effects of an abusive primary partner on the condom use and sexual negotiation practices of African-American women. American Journal of Public Health, 87(6), 1016-1018. 